\title{
THE EFFECT OF INJECTION OF NONSPECIFIC PROTEIN ON THE PAIN OF ULCER AND ON GASTRIC SECRETION: A CLINICAL AND EXPERIMENTAL STUDY
}

\author{
By FRANCES R. VANZANT ${ }^{1}$ AND ALBERT M. SNELL
}

(From the Division of Medicine and the Division of Experimental Surgery and Pathology, The Mayo Clinic, Rochester, Minn.)

(Received for publication January 21, 1932)

The search for additional forms of treatment for peptic ulcer refractory to the usual medical and surgical treatment has led to the introduction of many innovations. Among these is the injection of nonspecific protein, first introduced by Holler in 1921 (3) and later advocated by Pribram (9) and other investigators in Germany. Martin (4), Shaine (11), Meyer and Kartoon (6), and Schiff and Norris (10) have adequately reviewed the literature on this subject and outlined the development of this method of treatment. Briefly, it has been found that in cases of peptic ulcer symptoms of ulcer disappear completely for a variable length of time following the parenteral injection of various protein substances. Reports are at variance as to the percentage of patients who obtain relief, the duration of symptomatic improvement, and the probable effects of the procedure on the healing of ulcer. Also, little is known about the effects of the injection of foreign protein on gastric secretion and motility in normal and diseased human subjects. This paper sums up the results of work which we have done in an attempt to answer all these questions and in addition to determine the effects of the procedure on the gastric motor and secretory functions of dogs.

\section{CLINICAL OBSERVATIONS}

The difficulty of evaluating any treatment for peptic ulcer lies in the nature of the disease itself, with its great tendency to spontaneous remission and the almost equally great tendency to recurrence. Many observers have testified to the occurrence of symptomatic relief following injections of nonspecific proteins. Although such relief has been noted in intractable cases, the statement is often made that acute ulcers of short duration are more responsive to treatment by nonspecific protein than are chronic callous ulcers. In other words, good results are obtained in the group of cases in which the best results would be obtained by any treatment, and in which spontaneous remissions are most likely to occur even

${ }^{1}$ Fellow in medicine of the Josiah Macy, Jr., Foundation on duty in The Mayo Foundation. Work done in the Division of Experimental Surgery and Pathology. 
without treatment. In an attempt to avoid the possibility of assuming that what was really a spontaneous remission was due to our efforts at treatment, we studied only such patients as had had for some time symptoms so severe and intractable that spontaneous improvement was not likely to take place. None of the group of seventeen patients selected had improved materially under previous medical treatment. Moreover, all of them had had some form of surgical treatment, that is, they had submitted to one or more operations on the stomach. In every instance the diagnosis was based not only on a typical history but on a roentgenologic demonstration of a lesion, and in nine instances an ulcer was later demonstrated at operation. Four of the patients had recurrence of duodenal ulcers following operations on the pylorus; one patient had a large gastric ulcer persisting after gastro-enterostomy, and twelve patients had anastomotic ulcers. One of these twelve patients had recurrent ulcer following anterior gastro-enterostomy, six patients had ulcer following posterior gastro-enterostomy, and five, after partial gastric resection.

The ages of the patients ranged from twenty-four to fifty-one years; the average age was thirty-seven and five-tenths years. The average age at onset of dyspepsia was twenty-three and a half years; the youngest patient had had symptoms since the age of seven years. The duration of symptoms varied from five to twenty-four years, averaging fourteen years. Most of the patients had suffered severe symptoms and in every case the course of the disease was marked by many complications. Both medical and surgical treatment had been followed by indifferent or poor results. Thirteen of the patients had required more than one operation; of these two had required four operations each and one had required five operations.

\section{METHODS}

Many proteins have been used by various experimenters, but those most frequently employed have been a purified vegetable protein, known as "novoprotin," suspensions of killed bacteria, chiefly typhoid vaccine, and various sterilized and purified preparations of milk. There is no uniformity of opinion as to the degree of general reaction necessary to produce the maximal amount of benefit. We used Lederle's triple typhoid vaccine or Lilly's type " $\mathrm{H}$ " antigen intravenously in doses containing from $10,000,000$ to $60,000,000$ bacteria. An effort was made to secure a sharp reaction lasting a few hours with elevation of temperature not exceeding $3^{\circ} \mathrm{F}$. Usually four to six injections were given at intervals of three or four days. In a few instances $10 \mathrm{cc}$. of a purified preparation of milk (aolan) was given intramuscularly, a milder but definite reaction being produced by this means.

Before the injections of foreign protein were started, the patients were placed on a modified Sippy treatment for variable periods of time. After injections were begun changes in diet were not made until clinical 
improvement was noted. If, and when, improvement occurred the diet was made more liberal, but in no instance were the usual dietary restrictions exceeded that were considered necessary for the ambulant treatment of patients with ulcer.

Studies were made of the fasting contents of the stomach each morning for several days before the treatment was begun and daily thereafter to determine the influence of the treatment on gastric acidity. Besides the alcohol test meal, as devised by Bloomfield and Keefer (1), the Ewald test meal was used in a few instances before and after treatment to determine any change in secretory function.

\section{RESULTS}

Fourteen of the seventeen patients were relieved of symptoms of which pain, of course, was the most prominent, whereas the remaining three patients suffered marked aggravation of symptoms (Table 1). One of these three patients had duodenal ulcer associated with marked hypersecretion, one had an extensive penetrating gastrojejunal ulcer, and one had a poorly functioning gastro-enteric stoma and also gastric, duodenal, and anastomotic ulcers. Of the fourteen patients who experienced amelioration of symptoms, four had some degree of relief lasting for several days after each injection. One of these patients had a gastric ulcer which when observed fluoroscopically appeared to increase rapidly in size during the period of subjective improvement. One patient was so completely relieved of symptoms that he was allowed to return to his home; unfortunately the later course of the disease is unknown. Although two other patients were relieved of pain, the severity of the general reaction and the associated mental and emotional depression produced by the injections made them unwilling to continue the treatment. Four of the patients had a remission of one or more months before symptoms recurred; one had symptoms of pyloric obstruction three months later; one was relieved for several months when a second course of vaccine produced a similar period of remission, but epigastric pain and nausea have continued at intervals. The two other patients were relieved for about one month; one of these responded well again to a second course, but later returned with severe symptoms and a deep perforating jejunal ulcer; the other was made worse by a second course of vaccine, and at operation a large crater was found in the jejunum which had almost perforated into the colon.

The three remaining patients obtained more gratifying results. One was a young man who had symptoms of obstruction at the gastro-enteric stoma due to jejunal ulcer, the crater of which was visualized in the roentgenogram. He had little pain and no symptoms except those associated with obstruction. On a liquid diet, gastric retention of about $1,500 \mathrm{cc}$. of highly acid fluid was noted. After the first injection of 
vaccine, the amount of retention decreased markedly in spite of the fact that the amount and the coarseness of the food given were steadily increased. The fasting acidity dropped to an average value of 14 units and the stomach emptied normally. Several months later when there was a return of mild symptoms of obstruction vaccine was again given with good results. Since then the patient has had recurrent periods of obstruction which are relieved spontaneously, and in general he has remained reasonably well.

The second patient was a woman with mild and questionable symptoms of ulcer but a definite roentgenologic picture of gastrojejunal ulcer. Following two intravenous injections of typhoid vaccine she was almost entirely relieved of distress. In a week's time she gained 5 pounds, and

TABLE 1

Reaction before, during and after injection of nonspecific protein (clinical data)

\begin{tabular}{|c|c|c|c|c|c|c|c|}
\hline \multirow{2}{*}{ Case } & \multirow{2}{*}{$\begin{array}{l}\text { Age } \\
\text { and } \\
\text { sex }\end{array}$} & \multirow{2}{*}{ Ulcer } & \multirow{2}{*}{ Treatment } & \multicolumn{3}{|c|}{$\begin{array}{l}\text { Free acidity } \\
\text { in content of } \\
\text { fasting stomach }\end{array}$} & \multirow{2}{*}{ Results } \\
\hline & & & & 总 & 最总 & 娄 & \\
\hline 1 & \begin{tabular}{|c} 
years \\
34 \\
M
\end{tabular} & Gastrojejunal & $\begin{array}{l}2 \text { courses of } \\
\text { vaccine }\end{array}$ & $\begin{array}{c}c c . \\
\text { Nlio } \\
\text { per } \\
100 \\
c c . \\
92\end{array}$ & $\begin{array}{c}c c . \\
\text { N/io } \\
\text { per } \\
100 \\
c c .\end{array}$ & $\begin{array}{c}c c . \\
\text { Nlio } \\
\text { per } \\
100 \\
c c . \\
13\end{array}$ & $\begin{array}{l}\text { Relief of obstructive symp- } \\
\text { toms }\end{array}$ \\
\hline 2 & $\begin{array}{l}33 \\
\mathbf{M}\end{array}$ & Duodenal & $\begin{array}{l}4 \text { injections of } \\
\text { vaccine }\end{array}$ & 18 & $\mathbf{0}$ & 40 & $\begin{array}{l}\text { Relief for at least eight } \\
\text { months }\end{array}$ \\
\hline 3 & $\begin{array}{l}40 \\
F\end{array}$ & Castrojejunal & $\begin{array}{l}2 \text { injections of } \\
\text { vaccine }\end{array}$ & 30 & & $\mathbf{0}$ & $\begin{array}{l}\text { Improvement persisting for } \\
\text { at least two years }\end{array}$ \\
\hline 4 & $\begin{array}{l}35 \\
\mathbf{M}\end{array}$ & Gastrojejunal & $\begin{array}{l}4 \text { injections of } \\
\text { vaccine }\end{array}$ & 32 & & 61 & $\begin{array}{l}\text { Relief during treatment; later } \\
\text { course unknown }\end{array}$ \\
\hline $5^{-}$ & $\begin{array}{l}35 \\
\mathbf{M}\end{array}$ & Gastrojejunal & $\begin{array}{l}2 \text { injections of } \\
\text { vaccine }\end{array}$ & 30 & 16 & 52 & $\begin{array}{l}\text { Symptomatic relief, but re- } \\
\text { fused further treatment }\end{array}$ \\
\hline 6 & $\begin{array}{l}30 \\
\mathbf{M}\end{array}$ & Gastrojejunal & $\begin{array}{l}2 \text { injections of } \\
\text { vaccine }\end{array}$ & & & & $\begin{array}{l}\text { Pain relief, further treatment } \\
\text { refused }\end{array}$ \\
\hline 7 & $\begin{array}{l}45 \\
M\end{array}$ & Duodenal & $\begin{array}{l}4 \text { injections of } \\
\text { vaccine }\end{array}$ & 64 & & 56 & $\begin{array}{l}\text { Symptomatic relief for three } \\
\text { months, then developed } \\
\text { symptoms of obstruction }\end{array}$ \\
\hline 8 & $\begin{array}{l}33 \\
\mathbf{M}\end{array}$ & Duodenal & $\begin{array}{l}2 \text { courses of } \\
\text { vaccine }\end{array}$ & 20 & 4 & 58 & $\begin{array}{l}\text { Remission followed each } \\
\text { course }\end{array}$ \\
\hline 9 & $\begin{array}{l}51 \\
\mathbf{M}\end{array}$ & Gastrojejunal & $\begin{array}{l}2 \text { courses of } \\
\text { vaccine }\end{array}$ & 56 & 18 & 12 & $\begin{array}{l}\text { Prolonged relief from pain } \\
\text { but lesion progressive }\end{array}$ \\
\hline
\end{tabular}


TABLE 1 (continued)

\begin{tabular}{|c|c|c|c|c|c|c|c|}
\hline \multirow{2}{*}{ Case } & \multirow{2}{*}{$\begin{array}{l}\text { Age } \\
\text { and } \\
\text { sex }\end{array}$} & \multirow{2}{*}{ Ulcer } & \multirow{2}{*}{ Treatment } & \multicolumn{3}{|c|}{$\begin{array}{l}\text { Free acidity } \\
\text { in content of } \\
\text { fasting stomach }\end{array}$} & \multirow{2}{*}{ Results } \\
\hline & & & & 岕 & 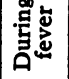 & 党 & \\
\hline 10 & $\begin{array}{c}\text { years } \\
37 \\
\mathrm{M}\end{array}$ & Gastrojejunal & $\begin{array}{l}2 \text { courses of } \\
\text { vaccine }\end{array}$ & $\begin{array}{l}\text { cc. } \\
\text { N/io } \\
\text { per } \\
\text { cco } \\
\text { cc. }\end{array}$ & $\begin{array}{l}\text { Nec. } \\
\text { per } \\
100 \\
\text { cc. }\end{array}$ & $\begin{array}{l}\text { cc. } \\
\text { N/10 } \\
\text { per } \\
100 \\
\text { cc. }\end{array}$ & $\begin{array}{l}\text { Complete relief for one month } \\
\text { from first course; none from } \\
\text { second course }\end{array}$ \\
\hline 11 & $\begin{array}{l}39 \\
\mathbf{M}\end{array}$ & Gastrojejunal & $\begin{array}{l}5 \text { injections of } \\
\text { vaccine }\end{array}$ & 30 & 35 & 62 & $\begin{array}{l}\text { Relief from pain for a few } \\
\text { days after each injection }\end{array}$ \\
\hline 12 & $\begin{array}{l}47 \\
\mathrm{M}\end{array}$ & Gastrojejunal & $\begin{array}{l}4 \text { injections of } \\
\text { vaccine }\end{array}$ & & & & Temporary relief \\
\hline 13 & $\begin{array}{l}42 \\
M\end{array}$ & Gastrojejunal & $\begin{array}{l}2 \text { injections of } \\
\text { vaccine and } \\
3 \text { of aolan }\end{array}$ & & & & $\begin{array}{l}\text { Complete relief from pain for } \\
\text { a few days }\end{array}$ \\
\hline 14 & $\begin{array}{l}50 \\
M\end{array}$ & Gastric & $\begin{array}{l}1 \text { injection of } \\
\text { aolan and } 2 \\
\text { of vaccine }\end{array}$ & 67 & 45 & 84 & $\begin{array}{l}\text { Temporary partial symptom- } \\
\text { atic relief but ulcer increased } \\
\text { in size }\end{array}$ \\
\hline 15 & $\begin{array}{l}35 \\
\mathrm{M}\end{array}$ & Duodenal & $\begin{array}{l}3 \text { injections of } \\
\text { vaccine }\end{array}$ & 44 & 34 & 35 & Aggravation of symptoms \\
\hline 16 & $\begin{array}{l}29 \\
\mathbf{M}\end{array}$ & Gastrojejunal & $\begin{array}{l}2 \text { injections of } \\
\text { vaccine }\end{array}$ & & & & $\begin{array}{l}\text { Marked aggravation of symp: } \\
\text { toms }\end{array}$ \\
\hline 17 & $\begin{array}{l}24 \\
M\end{array}$ & $\begin{array}{l}\text { Gastrojejunal, } \\
\text { d u o d en a l } \\
\text { and gastric }\end{array}$ & $\begin{array}{l}5 \text { injections of } \\
\text { vaccine }\end{array}$ & & & & Aggravation of pain \\
\hline
\end{tabular}

was able to return to her home. Two years later she reported that she was not entirely well but was much better than she had been. At a later visit to the clinic it was decided that the remaining symptoms could not be attributed to ulcer.

The third patient was a man who had had four operations on the stomach, the last one a pyloroplasty. At the time of admission he was having severe pain which suggested the presence of a perforating type of duodenal ulcer. After five injections of typhoid vaccine he was relieved satisfactorily and was able to return to work. Eight months later he reported that he was still free from distress although he found it necessary to continue on a restricted diet. 


\section{COMMENT}

It would seem from the foregoing that the results of protein treatment are usually inconstant and temporary although occasionally a patient will show a striking and fairly permanent improvement. In order to produce these results, it unfortunately is necessary that the patient be made to suffer more or less discomfort, sometimes so much that the treatment is more harrowing than the disease. Occasionally the temperature will rise to $104^{\circ} \mathrm{F}$. and the patient will be utterly miserable for twelve hours or more. At other times the reaction is delayed, the fever is prolonged and undesirable by-effects are likely to make their appearance.

An effort was made to determine which type of reaction was most likely to be helpful in relieving the symptoms of ulcer. A febrile response of less than $100^{\circ} \mathrm{F}$. rarely produced any definite effect. If reactions were accompanied by fever of more than $103^{\circ} \mathrm{F}$. the symptoms of ulcer were often aggravated. An abrupt febrile response of two or three hours' duration with a maximal temperature of $102^{\circ} \mathrm{F}$. was least disagreeable to the patient, and seemed most likely to produce relief from the symptoms of ulcer.

Of the fourteen patients who were benefited, twelve obtained relief from the first injection. This relief was often spectacular and patients who had been taking milk or alkali at frequent intervals throughout the night and who in addition had been taking opiates to control the pain were often completely relieved of distress within a few hours. Unfortunately, this relief was rarely permanent, the symptoms usually returning after a few days or weeks.

In the first few cases studied, we found what appeared to be a definite reduction in gastric acidity but in the larger group of cases studied later there did not seem to be any response to the treatment. The acidity of fasting contents removed during the course of a febrile reaction and while the temperature was still elevated was studied in six cases. The acid values were practically unchanged in two and distinctly lowered in four. In one case, the acidity was increased threefold a few hours after the termination of fever, a result comparable with that seen in our experimental animals. In all this work, titrations of fasting contents were made for a few mornings before treatment was instituted and then daily after the treatment. The readings obtained during the two periods were averaged separately so as to give a more trustworthy index of the conditions actually existing.

Similar studies of gastric juice obtained after the use of alcohol and Ewald meals showed the same absence of any constant change in acidity following the treatment.

There was no demonstrable correlation between the reduction of acidity and the degree of symptomatic relief obtained. In one instance, 
a rise of acidity from an average of 67 units before treatment to an average of 84 units after treatment was associated with relief of symptoms; later, after another injection when the acidity dropped to 63 units the pain became worse. It should be noted, however, that two of the three patients (Cases 1 and 3 in Table 1) who received the greatest benefit from the treatment showed the most marked decrease in acidity observed after the febrile reactions. Another patient who showed a considerable drop in acidity was relieved of symptoms after each of two courses of treatment, but ultimately had to resort to operation (Case 9).

\section{EXPERIMENTAL OBSERVATIONS}

When, with the first few cases studied, the gastric acidity seemed consistently to be reduced we became hopeful that the relief of symptoms was due to this change and that the use of vaccine had some possibilities in the treatment of ulcer. In an effort to learn more about this change in acidity experiments were begun in animals.

\section{METHOD}

Healthy young dogs of medium size were chosen for study. Aspiration of gastric contents was made, using a lavage tube passed in the same manner as in human subjects except that a wooden mouth gag was necessary to hold the jaws open. Aspirations were practiced repeatedly, day after day, until there was no longer any emotional reaction to the procedure. Fractional tests were then made several times a week over a period of many weeks until the curves for acidity on successive days were practically identical (Figure 1). More than 2,000 tests were made during the period of training, and 1,000 tests were made during the experimental period.

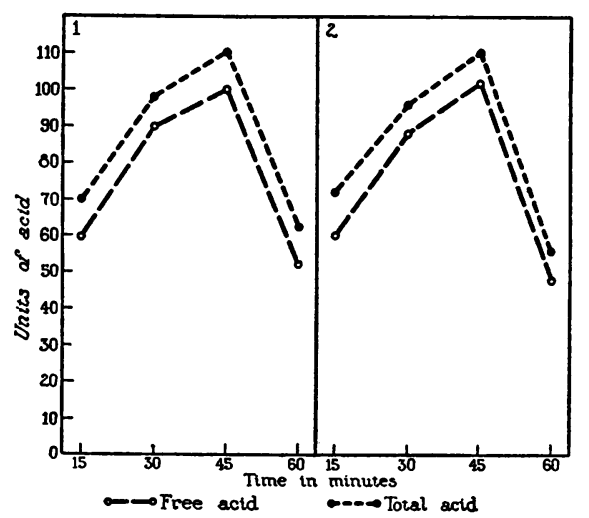

Fig. 1. Gastric Secretion Obtained from a Normal Dog. ACID IN CC. N/10 PER 100 CC.

The uniformity is shown of repeated tests possible in well-trained animals. Histamine injected 1 at 8:30 a.m., and $\mathcal{Z}$ at 11:00 on the same day. 
The test meal, which consisted of 80 grams of finely ground horse meat in $250 \mathrm{cc}$. of water, was fed in the morning after twelve hours of fasting. Small specimens were removed every fifteen minutes after the first half hour until the stomach was empty. The clear juice from a centrifuged sample of the contents was then titrated with 0.1 normal sodium hydroxide, using dimethyl-amino-azobenzene and phenolphthalein as indicators to determine free and total acids, respectively. The hydrogen-ion concentration was determined by means of a Leeds-Northrup potentiometer, using a quinhydrone electrode.

The gastric secretory response to histamine was also used as a measure of gastric function. For this test the stomach was aspirated as completely as possible every fifteen minutes following the injection of $1 \mathrm{mgm}$. of histamine subcutaneously.

To produce febrile reactions, various foreign proteins were given, but the intravenous injection of a suspension of a killed culture of Bacillus prodigiosus proved to induce fever more uniformly than any of the other substances employed. An initial dose of $100,000,000$ organisms was used and each subsequent dose increased by an amount which depended on the severity of the previous reaction, the object being to produce a temperature of about $104^{\circ} \mathrm{F}$.

As a rule the rectal temperature rose from normal of about $100^{\circ}$ to $104^{\circ} \mathrm{F}$. or more within two hours after the injection. While the fever was at its height, the gastric secretion was studied following stimulation with histamine since it was impossible to induce the dogs to take a test meal of meat during the febrile stage. When the fever subsided, which it did within two or three hours, the dogs had good appetites and were then fed their usual ration. The following morning the gastric secretion was again examined, using either histamine stimulation or a test meal of meat.

Bilateral intrathoracic section of the vagi had been done on three of the dogs two years before, and a fourth dog had had the branches of the vagus nerves sectioned below the diaphragm. The latter animal subsequently had the vagus nerves sectioned again within the thorax. Three additional dogs were operated on after a period of observation of their response to fever. Under ether anesthesia, administered intratracheally, with careful aseptic technic, both vagus nerves of one of them were cut in the thorax and intrathoracic portions of both splanchnic nerves were removed from the other two. After they had recovered from the operation, the response of gastric secretion to fever was again studied.

\section{RESULTS}

Dogs were found to vary markedly in susceptibility to fever. In two of the nine dogs used it was impossible to produce an adequate febrile reaction; it was readily produced in the remaining seven. During the 
course of the fever the dogs almost invariably appeared listless and sometimes they vomited. As soon as the temperature began to fall, they speedily recovered. The secretory response to histamine during the time that the temperature was rising or was at its peak was usually markedly subnormal, both as to volume of secretion and acidity (Figure 2). Often only a few cubic centimeters of thick bile-stained mucus could be obtained in which free acid could not be demonstrated. Rarely, and particularly when injections of protein were repeated at intervals of less than three days, both the volume and acidity of the gastric juice were only slightly reduced. Occasionally the stomach was filled with a large amount of fluid which had probably regurgitated from the intestine be-

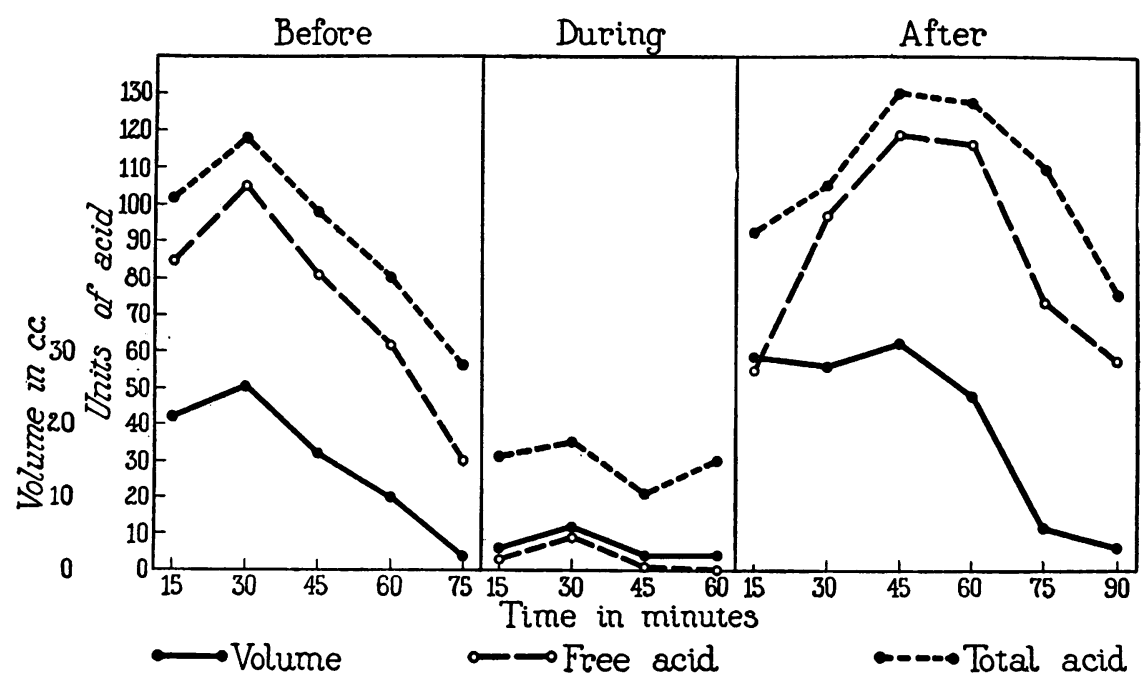

Fig. 2. The Volume and the Total and Free Acidity in cc. N/10 per 100 cC. Obtained from a Normal Dog Following Histamine Given Before, During, and the Day After Reaction to Protein Shock.

cause it had an almost neutral reaction and contained large amounts of bile. In $\operatorname{dog} 2$ (Table 2 ) the usual reduction in acidity during the reaction did not occur.

The decrease in secretion usually seemed to depend on the fever, because, except in Dog 1, it never altered until the temperature began to rise. Although in Dog 1 the temperature never rose higher than $102^{\circ} \mathrm{F}$. the animal would appear ill, and free hydrochloric acid would either be absent or very much reduced during a period of from four to six hours.

We can give some idea of the inhibition of gastric secretion produced by the fever by saying that all the juice that could be obtained after the injection of histamine during the febrile period could usually be neutralized by $12 \mathrm{cc}$. or less of 0.1 normal sodium hydroxide. 
TABLE 2

Secretion before, during and after injection of nonspecific protein (experimental data)

\begin{tabular}{|c|c|c|c|c|c|c|c|c|c|c|}
\hline \multirow{2}{*}{\multicolumn{2}{|c|}{ Animal }} & \multicolumn{3}{|c|}{ Volume } & \multicolumn{3}{|c|}{$\begin{array}{l}\text { Maximal } \\
\text { acidity }\end{array}$} & \multicolumn{3}{|c|}{$\begin{array}{l}\text { Total hydro- } \\
\text { chloric acid } \\
\text { obtained }\end{array}$} \\
\hline & & Dू & 葷 & 峞 & 岕 & 晃 & $\stackrel{\$}{\sharp}$ & 岕 & 晃 & 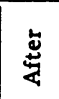 \\
\hline Dog 1. & Normal. & $\begin{array}{l}c c . \\
74\end{array}$ & $\begin{array}{l}c c . \\
13\end{array}$ & $\begin{array}{l}c c . \\
121\end{array}$ & $\begin{array}{c}c c . \\
\text { N/io } \\
105\end{array}$ & $\begin{array}{c}c c . \\
\text { N/io } \\
9\end{array}$ & $\begin{array}{c}c c . \\
\text { N/10 } \\
119\end{array}$ & $\begin{array}{c}c c . \\
\text { N/io } \\
64\end{array}$ & $\begin{array}{c}c c . \\
\text { N/io } \\
1\end{array}$ & $\begin{array}{c}c c . \\
\text { N/10 } \\
114\end{array}$ \\
\hline Dog 2. & Normal . . . . . . . & 85 & 77 & 131 & 77 & 91 & 98 & 56 & 49 & 94 \\
\hline \multirow[t]{2}{*}{$\operatorname{Dog} 3$} & Normal ........ & 58 & 36 & 76 & 90 & 62 & 101 & 43 & 12 & 81 \\
\hline & After cutting splanchnic nerve... & 58 & 25 & 70 & 77 & 16 & 90 & 37 & 1 & 56 \\
\hline \multirow[t]{2}{*}{$\operatorname{Dog} 4$} & Normal ......... & 70 & 22 & 100 & 97 & 27 & 107 & 57 & 8 & 81 \\
\hline & After cutting vagi. . & 55 & 12 & 18 & 51 & 0 & 32 & 20 & $\mathbf{0}$ & 9 \\
\hline \multirow[t]{2}{*}{ Dog 5} & Normal ........ & 58 & 24 & 97 & 88 & 27 & 81 & 44 & 5 & 62 \\
\hline & After cutting splanchnic nerve... & 73 & 35 & 83 & 79 & 20 & 80 & 49 & 5 & 51 \\
\hline \multirow[t]{2}{*}{ Dog 6} & $\begin{array}{c}\text { Two years after cutting vagi in } \\
\text { abdomen } \ldots \ldots \ldots \ldots \ldots \ldots \ldots\end{array}$ & 66 & 68 & 90 & 60 & 5 & 96 & 32 & 2 & 71 \\
\hline & After cutting vagi in thorax..... & 77 & 10 & 68 & 50 & 0 & 32 & 22 & 0 & 19 \\
\hline $\operatorname{Dog} 7$ & 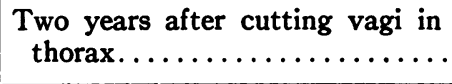 & 33 & 20 & 49 & 72 & 13 & 92 & 19 & 3 & 31 \\
\hline Dog 8 & $\begin{array}{c}\text { Two years after cutting vagi in } \\
\text { thorax } \ldots \ldots \ldots \ldots \ldots \ldots \ldots \ldots\end{array}$ & 28 & 18 & 75 & 53 & 15 & 98 & 12 & 2 & 59 \\
\hline Dog 9 & 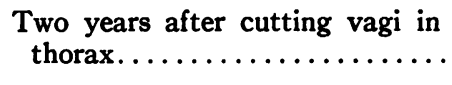 & 37 & 45 & 43 & 60 & 12 & 72 & 20 & 2 & 28 \\
\hline
\end{tabular}

On the day following the reaction to protein, the response to histamine was always as great as during the control period and in most instances it was definitely increased (Figure 3). Although only three animals secreted more than $50 \mathrm{cc}$. of 0.1 normal acid under normal conditions, nine of them exceeded this amount after a reaction (Figure 4 and Table 2). The level of free acid after a test meal of meat was likewise greatly elevated in the postfebrile period.

The period during which this increased secretory response could be obtained was brief. As a rule normal values for gastric acidity were obtained after forty-eight hours, although when injections of vaccine were repeated over two or three days the return to normal was retarded. 


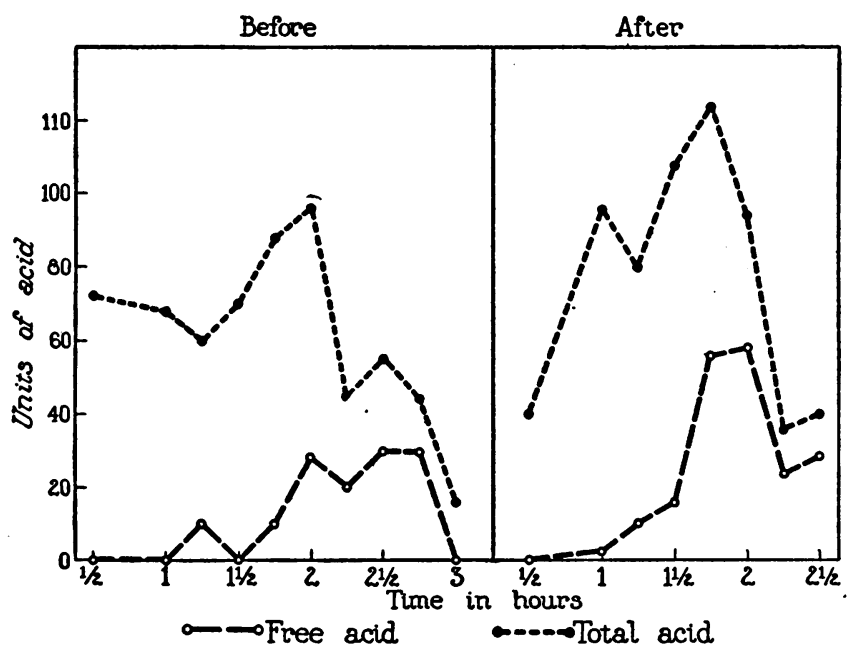

Fig. 3. The Total and Free Acidity in cc. N/10 Per 100 cc. After Test Meals of Meat Given the Day Before and the Day After Reaction to Protein Shock.

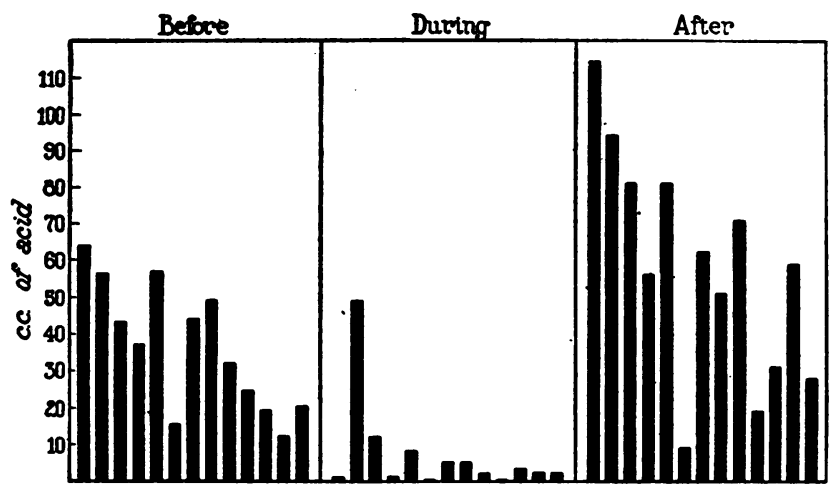

Fig. 4. The Average Amounts of Hydrochloric Acid Expressed as Cubic Centimeters of 0.1 Normal Acid Obtained in Each Dog Before, During, and After Reactions to Protein Shock.

The same order of presentation of data is used as in Table 2. Thus, the first bar in each of the three sections represents the first dog, the second bar represents the second dog, and so forth.

\section{COMMENT}

From these results it is apparent that the effect on gastric secretion of intravenous injections of foreign protein is biphasic with first a lessening of the juices and later an increased amount of fluid and acid.

An attempt was made to learn if their reactions were due to a direct effect of the protein injected on the secretory cell itself or an indirect one by way of the nervous system. In Nonnenbruch's opinion (7) the reac- 
tion to the injection to foreign protein produced first depression and later stimulation of all the cells of the body. Others, notably Holler (3), Pribram (9), and Petersen and Müller (8), have advanced the theory that the effects are due to an alteration of balance between the two hypothetic divisions of the autonomic nervous system. Meyer and Carlson (5) have shown that double vagotomy prevents the appearance of the gastric atony which appears during fever in normal dogs.

In our experiments section of the splanchnic nerves had no effect on secretion either before, during, or after injection of protein. Section of the vagus nerves, on the other hand, had a pronounced effect on secretion, as was shown by Hartzell (2). After this operation, the response to stimulation was always subnormal. In the dogs that had been operated on shortly before, we observed the expected reduction in volume and acidity of secretion during the febrile period, but after the fever had dropped these recently vagotomized dogs did not show the usual increase in secretory response. In dogs that had had vagus section performed several years earlier, both the febrile inhibition and postfebrile stimulation were typical of that seen in normal animals. Apparently the changes in the secretory mechanism that come immediately after vagotomy make it impossible for this mechanism to respond with increased activity during the postfebrile period. As one of us (12) has pointed out elsewhere, the stomach seems to be able after several years to adjust itself to the loss of vagal influence and then its secretion becomes almost normal again. This probably explains why in the animals long accustomed to vagotomy the secretory response to protein injections differs from that observed in the dogs which have recently been operated on.

\section{SUMMARY AND CONCLUSIONS}

In dogs the intravenous injection of foreign protein produces first a brief lowering in the amount and acidity of the gastric juice and then a more prolonged rise in the activity of the secretory mechanism.

Section of the vagus or splanchnic nerves did not materially influence the response of the gastric glands to injections of foreign protein except for the fact that immediately after bilateral vagotomy the secondary increase in secretion was abolished.

In cases of ulcer, the injection of foreign protein was frequently followed by a gratifying reduction in the amount of pain and distress. This clinical improvement was not associated with any consistent lowering of gastric acidity and there was no correlation between the degree of acidity found at any one time and the amount of pain complained of. There was some indication in the patients of the presence of the same biphasic swing in secretion that was found in dogs.

There was some evidence to indicate that more lasting relief of symptoms can be expected in those cases in which the secretion is reduced after treatment. 
Only three of the seventeen patients treated obtained relief which lasted for some time while four had temporary relief. Four of the patients experienced such brief periods of relief and the febrile reactions were so unpleasant that it did not seem advisable to continue the treatment. The condition of the ulcer of three patients grew worse during the period of treatment and observation, although all of these obtained some symptomatic relief. The symptoms of the remaining three patients were aggravated by the treatment.

The clinical and experimental data here presented have left us with the impression that injections of foreign protein are not likely to be of much value in the treatment of peptic ulcer except in occasional cases. The discomfort entailed did not justify the results obtained.

We have no exact information which would warrant our making guesses as to the mechanism which in some cases produces prompt relief of pain and discomfort.

\section{BIBLIOGRAPHY}

1. Bloomfield, A. L., and Keefer, C. S., Arch. Int. Med., 1926, xxxvii, 819. A Method for the Continuous Quantitative Estimation of Gastric Secretion and Discharge in Man.

2. Hartzell, J. B., Am. J. Physiol., 1929, xci, 161. Effect of Section of the Vagus Nerves on Gastric Acidity.

3. Holler, Gottfried, Wien. klin. Wchnschr., 1921, xxxiv, 223. Ist eine organische Vaguserkrankung die Ursache des Ulcus ventriculi chronicum beim Menschen? Die Grundlagen zu einer neuen Therapie des Ulcus ventriculi et duodeni.

4. Martin, Lay, Arch. Int. Med., 1929, xliii, 299. Peptic Ulcer: the Effect of Parenteral Injections of Purified Milk Proteins on the Symptoms and Progress.

5. Meyer, Jacob, and Carlson, A. J., Am. J. Physiol., 1917, xliv, 222. Contributions to the Physiology of the Stomach. XLIII. Hunger and Appetite in Fever.

6. Meyer, Jacob, and Kartoon, L. B., Arch. Int. Med., 1930, xlvi, 768. The Effects of Intravenous Injections of Foreign Protein on Peptic Ulcer.

7. Nonnenbruch, München. med. Wchnschr., 1928, 1xxv, 161. Die physiologischen Grundlagen der Proteinkörpertherapie.

8. Petersen, W. F., and Müller, E. F., Arch. Int. Med., 1927, xl, 575. The Splanchnoperipheral Balance during Chill and Fever.

9. Pribram, B. O., Med. Klin., 1922, xviii, 958. Parenterale Reizbehandlung des Magen- und Duodenalgeschwürs.

10. Schiff, Leon, and Norris, R. J., J. Med., 1931, xii, 179. Non-specific Protein Therapy in Duodenal Ulcer.

11. Shaine, M. S., Med. J. and Rec., 1929, cxxx, 30. The Treatment of Peptic Ulcer by Protein Injection.

12. Vanzant, F. R., Am. J. Physiol., 1932, xcix, 375. Late Effects of Section of the Vagus Nerves on Gastric Acidity. 